\title{
REFLECTIVE THINKING STRATEGIES FOR DEVELOPING EFL LITERARY READING SKILLS AND METACOGNITIVE READING AWARENESS
}

\author{
Eman Mahmoud Ibrahim Alian \\ Faculty of Sciences and Arts \\ King Khalid University (KKU), Saudi Arabia \\ E-mail: aalayan@kku.edu.sa
}

Received: 27 October 2019

Accepted: 26 November 2019

\begin{abstract}
The present study is aimed at examining the effect of reflective thinking strategies on developing literary reading skills and metacognitive reading awareness of the EFL student teachers. The study adopted the quasiexperimental design. One experimental group of 40 major English students at the third-year Faculty of Education, Zagazig University in Egypt, participated in the study. The treatment conducted in fourteen sessions through teaching King Lear drama by Shakespeare. The utilized instruments included a literary reading test that was developed and used as a pre-post test and a metacognitive reading awareness scale, which was also designed by the researcher and approved by the jury members. Parametric statistical calculations have used for data analysis through the SPSS program. Results revealed that reflective thinking had a positive effect on developing literacy reading skills and metacognitive reading awareness of the EFL student teachers.
\end{abstract}

Keywords: reflective thinking, literary reading, metacognitive awareness, EFL student teachers.

\section{Introduction}

Reading is one of the most important lifelong learning skills for all learners as it enables them to gain information in different fields of life. Besides, it is a means of learning in all subject areas. Through reading, one can interact with other different cultures and benefit from them at the same time. Extensive exposure to various reading passages sets the stage for thinking about and discussing very crucial matters.

Reading literature evokes the readers' minds to think through its events and to find meanings behind words. It also broadens their experiences and gives them opportunities to learn the four language skills. Van (2009) stated that for many university teachers of English as a foreign language, the study of literature is indispensable because it exposes students to meaningful contexts that are replete with descriptive language and interesting characters. Structuring lessons around the reading of literature introduce a profound range of vocabulary, dialogues, and prose. In addition to developing students' English language skills, teaching literature also appeals to their imagination, promotes cultural awareness, and encourages critical thinking about plots, themes, and characters.

To be actively engaged in the process of reading, students should be aware of their cognitive processes, their employed strategies, and how to regulate them. Therefore, there is a close relationship between the process of reading and awareness. Mokhtari and Sheorey (2002) clarified that the term metacognitive awareness includes readers' conscious 
Reflective Thinking Strategies for Developing EFL Literary Reading Skills and Metacognitive Reading Awareness, Eman Mahmoud Ibrahim Alian

awareness of strategic reading processes, of the reading-strategy repertoires, and of their actual utilization of the strategies to maximize text comprehension. Hudson (2007) revealed that readers with stronger metacognitive awareness display hint to interpret a reading task based on context requirements. He added that they select reading strategies concerning reading purposes, task demands, and their cognitive style. Moreover, they monitor the process of comprehension, evaluate the effects of the chosen procedures, and adjust strategies when needed.

When shedding light on the state of teaching literature at the university level in Egypt, El-Henawy (2007:8) argued that EFL students have not adequately prepared for the new tasks of reading literary texts in college courses. They need to be trained to discuss, analyze, and interpret literary and cultural topics at a more sophisticated level in order to cope with the challenges that literature course offers. She suggested that much attention should be directed towards developing these skills and stressed the need for new strategies, techniques, and programs for teaching and developing them.

A pilot study was conducted to the third-year English majors at the Faculty of Education, Zagazig University in Egypt to find out the real problems facing them concerning the literary reading skills and the metacognitive reading awareness and to what extent they master these skills. A diagnostic literary reading test was designed and administered to 36 students (Appendix.1). It was revealed that the percentage of practicing literary reading skills was $30.2 \%$, which was an unacceptable percentage for students at such a level. As for measuring students' metacognitive awareness, Sheorey and Mokhtari's metacognitive reading awareness scale (2002) (Appendix. 2) was administered among the same sample. Results revealed that students' awareness level was $42,8 \%$, which was not convenient either.

There is a close relationship between the process of thinking and reading literature. Through reading, students are engaged in processes such as: making connections between previous and current incidents, interpreting symbols, analyzing character's behaviors, discovering new relationships, and making inquiries. This means that they reflect on the whole reading situation. Therefore, encouraging students to employ thinking strategies could be a useful tool for teaching literature. Hennings (1992) clarified that reading and reflecting are closely related. By reflecting on literature, children and youth can acquire critical basic thought processes. Thus, students at every level should have numerous opportunities to read and reflect on stories and poems.

Brevig (2009) pointed out that reflection is crucial in each student's understanding of texts and helps build a productive conversation around literature and important sociocultural themes. He added that reflection had high power in the building of collaborative, literate, democratic, and inclusive classroom communities. Al-Hazmi (2006) illustrated that deep-level reflection and critical thinking are vital strategies that might help learners in the acquisition of new EFL language skills.

Based on the results of the pilot study which revealed the weakness in students' mastery of literary reading skills and their metacognitive reading awareness, the current study is an attempt to employ some reflective thinking strategies for developing literary reading skills and metacognitive reading awareness of the EFL student teachers.

\section{Literature Review}

\subsection{Theoretical Framework}

Dewey, in his book "How we Think, 1933" was the first researcher who presented the term reflection into literature. He was interested in the process of reflection, and how it 
occurred. Dewey conceptualized reflective thought as a mental process that originated with a state of doubt and then expanded into a search for ways to ease that doubt. Reflective thinking includes a higher degree of uncertainty and personal doubt. As such, it is more likely to soar beyond existing knowledge and standards as human imagination opens the door to new possibilities. A reflective thinker tends to carefully consider and ponder new possibilities when confused, bewildered, or filled with doubt; these characteristics illustrate the openminded element of proper attitude (Geertsen, 2003). Dewey's definition of reflective thinking considers actions to find and solve problems (Nottingham, 1998). Therefore, reflective thought involves the acquisition of facts, understanding of ideas, application of principles, analysis, synthesis, and evaluation. In short, reflective thought includes all levels of Bloom's taxonomy (Shermis, 1999).

In practicing reflective thinking through reading, students seek to relate incidents with each other to discover new meanings. Chi (1997: 11) mentioned that reflective thinking encourages students to make connections between what they know and what they are finding out as a result of a new experience; moreover, it allows students to link things together and helps them to see new relationships. In other words, it has become the experience of discovery, of uncovering this range of meanings in texts. He concluded that reflective thinking becomes power readers choose to exercise in the analysis and transformation of information of situations in which they find themselves when they pause to reflect.

Brevig (2009) pointed out that reflection is crucial in each student's understanding of texts and helps build a productive conversation around literature and important sociocultural themes. He added that reflection had a high power in the building of collaborative, literate, democratic, and inclusive classroom communities. Al-Hazmi (2006) illustrated that deep-level reflection and critical thinking are vital strategies that might help learners in the acquisition of new EFL language skills.

Reflective thinking strategies were chosen because many studies recommended using new approaches and strategies for developing students' literary reading skills and metacognitive reading awareness. Scanlan, Care, and Udod (2002) clarified that the use of reflection in education emerged as an effective means of connecting theory with practice. However, literature revealed limited empirical work on the conceptualization of reflection, and there had been little concerted effort to investigate reflective strategies in teaching. Zayed (2009) added that there is a considerable body of literature on reflective teaching to train pre-service or in-service teachers to be aware of the effect of their professional practices. However, there is not a similar body of research using reflection for developing language learning.

\subsection{Reflective Thinking}

The concept of reflection, or what is commonly referred to as "reflective thinking, received great attention in the areas of teaching and learning. John Dewey was the first researcher who presented the term reflection into literature. He was interested in the process of reflection and how it occurs. Josten (2011: 33) clarified that the origins of reflective thinking began with the work of Dewey "how we think" (1933), in which he referred to reflective thinking as the thinking that consists of turning a subject over in mind and giving it serious and consecutive consideration. From this definition, it is apparent that the reflective thinker should use his mind to carefully consider each learning situation and not to accept any matter at face value. Therefore, reflective thinkers should be engaged in 
Reflective Thinking Strategies for Developing EFL Literary Reading Skills and Metacognitive Reading Awareness, Eman Mahmoud Ibrahim Alian

the process of inquiry. Reid and Gloub (1999) indicated that reflection is a valuable process of questioning, connecting ideas, analyzing, and forming opinions.

The reflective thinker stops to think deeply in the subject at hand, turns it over in his mind, and evaluates it. He tries to analyze the presented material for distinguishing the relevant from irrelevant and the fact from opinion. At the same time, he organizes information to connect them logically. The reflective thinker is a critical thinker at the same time. He is aware of and controls his learning by participating actively in the learning process.

Utilizing reflection through reading literature can play an essential role in developing students' understanding and interpretation of the text. It gives them opportunities to present their points of view, negotiate meanings, and discuss the provided shreds of evidence until discovering and evaluating the author's intended message. In this context, Mezirow (1991:11) mentioned that making meaning is central to what learning is all about. Reflection becomes critically important in learning to understand the meaning. Brevig (2009:3) indicated that the spaces created for talk, reflection, critical thinking, and literary exploration are crucial in each student's understanding of texts. He also explained that observation has excellent power in the building of collaborative, literate, democratic, and inclusive classroom communities. It provides the space for considering what students have learned and the opportunity to reflect upon their inquiries, curiosities, emotions, and thinking leading up to one's current understanding.

Smith (1997) asserted that reflection provides a more profound understanding. It is crucial to learning and thinking. It moves students along the learning continuum. He also mentioned that active reflection on literature occurs by allowing students time to "stop and think" and then actively reveal this thinking by sharing it in class. He added that this happens through three phases: reflecting on previously read literature, engaging in a period of reaction, and writing. Through the integration of these three components, the teacher can guide students through reflection and enhance educational experiences.

\subsection{Reflective Thinking Strategies and Activities}

Thoughtful strategies and activities are designed to facilitate meaning-making and the construction of knowledge. They include journal writing or specific assignment integrated into course design to help learners move beyond a surface, knowing to a deeper level of understanding. Reflective strategies and activities view as ones that enhance opportunities for metacognitive awareness and personal discovery (Andrusyszyn, 1996:14).

Holt (2006) clarified that the reflective journals help foster and create an environment so students can discover their interpretation, create their meaning, and plan an application. Brookfield (1995) indicated that reflective journals contribute to a student's ability to question, investigate, and understand his learning.

Another distinct type of journal is the response journal that commonly uses in studying literary texts. It enables students to reflect on their thinking, provides a means for the development of the inner voice of "self-talk". They also can share feelings, impressions, and other observations about literature. The response can be written before, during, and after the reading of a selection. Sentence stems can be provided to stimulate thoughtful reflections. Some examples of these are: I noticed..., I wonder..., this reminds me of (Costa and Kallick, 2000).

One prominent strategy that prompts students' reflective thinking through reading is the "exploratory talk" that takes the form of metacognitive inquiry. According to Davenport 
(1993:180-181), the metacognitive research is a conversation between a teacher and a student or among several students during which the reader is assisted in actively constructing meaning by talking about the process of thinking and understanding a text. Brevig (2006:523) clarified that when readers stop to comment on the language of a document or to explore their understanding of it, they are actively engaged in the process of uncovering meaning, transacting with both the text and their fellow readers.

Retrospective Reflection Sessions involve students listening to their group members, thinking about, and talking about literature. The power to return to a text and reflect upon themes that surfaced during conversations is invaluable. It helps students to understand that there are no singular interpretations of a document, that teachers are interested in their insights, and that their opinions are valued. (Brevig, 2009:244)

Cranton (2006:138) asserted the use of questions in encouraging learners to think reflectively and critically. He mentioned that through thinking about and responding to questions, new avenues for understanding, and new ways of seeing things are opened. In answering questions, learners have an opportunity to search for individually meaningful solutions to problems.

Visualization is an effective strategy for developing student's reflective responses. It is the act of drawing a mental image in one's mind. Gunning (2000) stated that mental imaging has many benefits; it promotes the use of prior knowledge and improves the reader's ability to make predictions and inferences. Barton et al (2001) clarified that visualizing while reading not only develops meaning from a text but also brings the text to life for the reader based on his or her experiences.

Other strategies concerning applying reflection through reading utilized. Especially, reflecting on literature. Hennings (1992) provided some primary ways through which students can reflect on literature. These strategies include anticipating and predicting, inferring, the read aloud, and the literary conversation. Some more strategies presented by Richardson, Morgan, and Fleener (2009) were brainstorming, post-graphic organizers, thinkpair-share, think aloud, the about/point strategy, text lookbacks, and group summarization.

\subsection{Literary Reading}

Literature is a vital source for acquiring various skills of language and learning how to use them at the same time. Moreover, it encourages learners to explore meanings and motivates them to learn more about different cultures. In supporting this view, Ur (1996: 201) mentioned that literature provides examples of different styles of writing, and representations of various authentic uses of the language. At the same time, it is a useful resource for increasing word power and encourages developing different reading skills. He also added that literature could be used as a springboard for exciting discussion or writing. It involves both emotions and intellect, which adds to the motivation and may contribute to the personal development of the student.

Readers' emotions cultivate through their interaction with the heroes of different literary works. They experience various emotions, such as admiration, sorrow, gratitude, etc. They may also dream of finding such heroes in their real life. Sawira, Suhadi, and Manugeren (2017) stated that there always seems to be a hero in everyone's life; everyone has one, and many act as one. A hero is simply a man admired for his achievements and noble qualities. Heroes have been constructed in many fictional literary works and myths, as well as in reality. 
Reflective Thinking Strategies for Developing EFL Literary Reading Skills and Metacognitive Reading Awareness, Eman Mahmoud Ibrahim Alian

The idea of enriching thinking skills through studying literature was echoed by Shang (2006) who mentioned that the focus of literature teaching is not only to help students comprehend the meaning that the author tries to express, but also to enhance students' thinking and language abilities, as well as study skills. He maintained that through literature, students have to learn vocabulary, discover questions, evaluate evidence individually and in group discussions, form judgments based on synthesis and analysis, and develop a coherent argument in support of a position. Lazer (2005: 3) clarified that using literature in the classroom is a fruitful way of involving the learner as a whole person and provides excellent opportunities for the learners to express their personal opinions, reactions, and feelings. He extended that teachers should use literary texts as the basis for generating discussion, controversy, and critical thinking in the classroom.

Through reading literature, each student creates his end. Thus, it inspires students' imagination and encourages autonomy in learning. Van (2009:8) stated that research has the power to develop opinions and individual meanings for students; hence, they will typically be the ones to initiate and sustain activities based on the literary themes that resonate with them. This will help students become active classroom participants and will lead to autonomous learning. Besides, while reading, they would forge secure connections with the plots, themes, and ideological assumptions of literature and would become active learners that embrace critical thinking in English.

\subsection{Metacognitive Reading Awareness}

Researches proved that proficient readers apply different strategies through reading, know when and how to use them, and monitor their progress to see if they achieve their goals or not. The readers' awareness of this usage is of high importance as they can apply different alternatives that can help them to control their reading, proceed it successfully and work to improve it. Sheorey and Mokhtari $(2001,432)$ mentioned that the strategies that students use while reading, especially in a language other than the mother tongue, becomes very important in comprehension and development of this skill. They maintained that in the last two decades, considerable attention had given to comprehending what proficient, skilled readers commonly do when reading, identifying the strategies they adopt and determining how and when they use them.

Auerbach and Paxton (1997: 240-241) explained that metacognitive awareness entails knowledge of strategies for processing texts, the ability to monitor comprehension, and the ability to adjust policy as needed. Learners' awareness and strategies monitoring are known as metacognition. Flavell (1979) was the first who defined metacognition as one's ability to understand, control and manipulate his cognitive process to maximize learning.

Metacognition consists of two components: knowledge and regulation. Metacognitive awareness includes knowledge about oneself as a learner and the factors that might impact performance, experience about strategies, and learning about when and why to use strategies. Metacognitive regulation is the monitoring of one's cognition, and it includes planning activities, awareness of comprehension and task performance, and evaluation of the efficacy of monitoring processes and strategies (Lai, 2011:2).

Metacognitive awareness is a unique attribute of proficient readers. Zhang et al. (2008) illustrated that successful readers generally display a higher degree of metacognitive awareness, which enables them to use reading strategies more effectively and efficiently than their unsuccessful peers. Schraw and Dennison (1994) stressed this point as they stated that highly metacognitive individuals do better than others in planning, managing 
information, monitoring, debugging and evaluating. Blank (2000) added that the metacognitive learner is believed to be characterized by the ability to recognize, assess, and where needed to reconstruct existing ideas.

\section{Research Method}

\subsection{Design and Participants}

The present study is both descriptive and quasi-experimental. Only one group was randomly assigned to be a pre-post experimental group. A pre-post test and a pre-post scale were given to the students before and after the treatment. A group of forty students English major at third-year Faculty of Education, Zagazig University in Egypt, was randomly chosen to be the participants of the present study, both male and female students. Their average age ranged from 19-20 years old. They informed that their participation in the experiment is beneficial for them. Thus, they participated positively and actively throughout the test.

\subsection{Procedures}

The reading material used in this study was the play of King Lear by Shakespeare. The program was taught in 1or 2 sessions per week over eleven weeks (approximately three months). Therefore, this content took 28 hours. It consisted of 14 sessions. The reflective thinking strategies and activities were utilized through the three stages of reading: pre, during, and post as follows:

\section{Pre-reading stage}

(Setting the stage for reflection)

In this stage, the instructor encouraged students to be involved in these activities: Brainstorming: They were encouraged to give all their ideas, perspectives, and points of view about the subject of discussion by giving them a specific quotation or asking them a question concerning the act that will be discussed.

Activating prior knowledge: in this activity, students were asked questions to make connections between the previous incidents and the current ones, the characters' behaviors, the plot development, and the central theme of the work. Instructor asked questions like:

What do you already know about...?

Have any of you ever experienced...?

What have you read before about...?

Make a comparison between the character's behavior in this situation and another one. When you read the word or phrase ..., it makes you think about...

Anticipating and predicting: the instructor promoted students to predict future incidents and characters' actions based on their previous reading and asked them to evaluate their predictions and tried to refine them in the reading stage. Examples of the questions used were:

What do you think would happen next?

In your opinion, what would be the destiny of...?

The instructor also used an anticipation guide by creating some statements about the specific actions that would be discussed. Students read each statement and agreed or disagreed with it. They had to put an answer for each report. After reading, students could revise and verify their responses based on what they discovered through reading. This guide could also be used in the during reading and post-reading stages in discussing the validity of its statements. 
Reflective Thinking Strategies for Developing EFL Literary Reading Skills and Metacognitive Reading Awareness, Eman Mahmoud Ibrahim Alian

\section{During reading stage \\ (Practicing Reflection)}

A variety of reflective thinking activities was practiced in this stage according to the nature of the literary text such as:

Think aloud: students were encouraged to express their thoughts, feelings, and attitudes and at the same time, difficulties in understanding as they read. They were also motivated to question the author. Students could use these prompts to express their understanding:

This made me think of...

That didn't make sense because....

I need to reread that part because...

I was confused by...

Asking reflective questions: the instructor here asked students questions and gave them opportunities to think deeply about the answer through examining the text. These questions were about the author's message, the characters' behaviors, their relationships, and their beliefs, the plot development, the central conflict, and the coming incidents of the literary work. An instructor could ask questions like:

How can you describe...?

What is your impression about...?

Make a comparison between....

What is the reason behind the character's behavior in that situation?

What is the reason behind the character's behavior in that situation?

Visualizing: through reading the literary work, students can draw or write responses with details. The instructor could ask questions like:

Can you imagine the scene the words describe?

Does this remind you of anything in your life?

Students could also use a simple character action web to make inferences about a character. They wrote the name of a role in the middle of a sheet. Connected to the title, they wrote down things this character did (Hennings, 1992).

Making connections: They included "that reminds me," "text- to- self, text-to-text, textto-world, and text-to-author. The strategy "that reminds me" encouraged students to make a connection between what they are reading and prior knowledge. The strategies of text-toself, text-to-text, text-to-world, and text to author encouraged students to make connections between themselves and writing, other literature, the world, and authors (Harvey and Goudvis, 2000).

Predicting: The instructor encouraged students to anticipate the coming incidents through reading. They were also encouraged to test their predictions, confirm, modify, reject, and make further predictions as they proceed.

The literary conversation: students were encouraged to interact actively with their peers through expressing their ideas, perspectives, and feelings about the literary texts. They could converse about the topic, the characters, the setting, and the theme. As through reading aloud, they stopped a few critical spots for literary conversations. These brief pauses in a read-aloud were times for listeners to talk about the predictions they made, to make new predictions, to express feelings, and to make connections.

\section{Post reading stage}

(Enhancing and extending reflection)

The instructor encouraged students to practice these activities: 
Journal writing: In this activity, students could reflect critically on their reading through writing in:

Reflective journals: in this journal, students were encouraged to express in writing what they read, how they felt, and how they used their experience. Students were also encouraged to question the literary text to understand it.

The Reading Log: It was introduced as a place to write about an intellectual journey, exploring readers' thinking about reading. It was not a summary; students were given questions to encourage them to focus on the issues at hand Kuhn (1999:89).

Questions/prompts, with intended cognitive activities, were presented as follows:

Reading Log Questions

What is your responsibility as a reader to the piece, and why?

Did this piece of writing make you think about your life?

What made the most impact upon you, and why?

What did not you understand, or what questions does it raise?

Retrospective Reflection Sessions: The power to return to a text and reflect upon themes that surfaced during conversations is invaluable. Retrospective reflection sessions allow students to slow down and think about the discussions and the meanings they brought to the text. They helped them tie together the loose ends of the story, share their final thoughts, and look ahead to where they want to go next in their reading Brevig, 2006:527).

\subsection{Instruments}

The present study made use of two primary tools. They are the pre-post literary reading skills test to measure students' literary reading skills and the pre-post metacognitive reading awareness scale to measure students' metacognitive reading awareness through reading literary texts. The two instruments were designed by the researcher. The test was pre and post used to measure the effectiveness of the strategies on developing the experimental group students' literary reading skills. The experiment consisted of twenty-four questions on a one-act play "The Never- Never Nest" by Cedric Mount. Two questions were formulated to measure each skill. To test the validity of the literary reading test, two forms of validity were used; face validity and self validity. To check the face validity, the test was given to (10) TEFL members to evaluate each question in terms of content and level of the measured literary reading skills. Moreover, they were asked to assess the test as a whole in terms of correctness, the number of questions, scoring suitability for the students' level, the test suitability for students' age, and the suitability for its time limits. To test the self validity, the following formula was used:

$$
\begin{aligned}
& \text { The self validity }=\sqrt{\text { Reliability }} \\
& =\sqrt{0.79}=0.88
\end{aligned}
$$

This proved that the literary reading skills test was statistically valid. The final version of the test is in (Appendix 3)

To verify the test reliability, the internal consistency method was used. Cronbach's Alpha technique was calculated by (SPSS) program. Accordingly, the literary reading skills test was administered to a randomly chosen group of (42) English major students in the third 
Reflective Thinking Strategies for Developing EFL Literary Reading Skills and Metacognitive Reading Awareness, Eman Mahmoud Ibrahim Alian

year, Zagazig Faculty of Education. These students were not included in the study group. The test reliability was 0.79 . This result proved that the literary reading skills test was statistically reliable.

The scale consisted of thirty-three items for measuring the metacognitive awareness of strategies through reading literary texts. The metacognitive reading awareness scale measures three broad categories of reading strategies: namely, global reading strategies, problem-solving strategies, and support strategies. This classification was adopted from Mokhtari and Sheorey's ranking of reading strategies (2002). The description of each category with its respective number of items are given below:

Global Reading Strategies (GLOB): they are the intentional, carefully planned techniques by which learners monitor or manage their reading, such as having a purpose in mind, activating prior knowledge, skimming through the literary work to identify its theme, and analyzing the literary work to determine its elements (13 items).

Problem Solving Strategies (PROB): they include the actions and procedures that readers use while working directly with the text. These are localized, focused techniques used when problems develop in understanding textual information; examples include rereading difficult parts to understand them, creating mental images through reading to deepen understanding, and guessing the meaning of difficult words from the context. (8 items).

Support Strategies (SUP): they are underlying support mechanisms intended to aid the reader in comprehending the text, such as using a dictionary, reading aloud, writing marginal notes, underlining the essential parts, and listing the most important ideas (13 items).

To test the validity of the scale, two aspects of validity were used; face validity and selfvalidity. To test the face validity, the scale was given to (10) TEFL members to determine whether the scale items were enough to measure the metacognitive reading awareness of students or not. They were also asked to modify, omit, or add to these items whatever they consider important.

To test the self-validity, the following formula was used:

$$
\text { The self validity }=\sqrt{\text { Re liability }}=0.84
$$

This proved that the metacognitive reading awareness scale was statistically valid. The final version of the scale is in (Appendix 4). The whole scale reliability was 0.72 . This result proved that the metacognitive reading awareness scale was statistically reliable.

\section{Results and Discussion}

To test the first hypothesis of the study which stated that: There would be a statistically significant difference between the mean scores of the experimental group in the pre- and the post-test scores in overall literary reading skills and each sub-skill favoring the post-test scores, a t-test was used. The result is shown in table (1).

Table (1)

t-values of the experimental group in the pre and the post administrations of the literary reading test as a whole and in each sub-skill. 


\begin{tabular}{|c|c|c|c|c|c|c|}
\hline $\begin{array}{l}\text { Literary reading } \\
\text { skills }\end{array}$ & $\begin{array}{l}\text { Pre } \\
\text { Mean }\end{array}$ & $\begin{array}{l}\text { post } \\
\text { Mean }\end{array}$ & $\begin{array}{c}\text { Pre } \\
\text { Std. } \\
\text { Deviation }\end{array}$ & $\begin{array}{l}\text { Post Std. } \\
\text { Deviation }\end{array}$ & t. Values & Sig \\
\hline $\begin{array}{l}\text { 1. Making } \\
\text { inferences }\end{array}$ & 1.2000 & 2.8750 & 0.85335 & 0.85297 & 8.780 & $0.01^{*}$ \\
\hline $\begin{array}{l}\text { 2. Analyzing the } \\
\text { plot }\end{array}$ & 1.1500 & 2.9000 & 0.92126 & 0.70892 & 9.521 & $0.01^{*}$ \\
\hline $\begin{array}{l}\text { 3. Analyzing } \\
\text { characters }\end{array}$ & 1.0000 & 3.4000 & 0.71611 & 0.67178 & 15.459 & $0.01^{*}$ \\
\hline $\begin{array}{l}\text { 4. Expressing } \\
\text { opinions }\end{array}$ & 1.3750 & 3.6750 & 0.77418 & 0.57233 & 15.109 & $0.01^{*}$ \\
\hline $\begin{array}{l}\text { 5. Determining } \\
\text { the author's } \\
\text { purpose }\end{array}$ & 1.4000 & 3.4500 & 1.05733 & 0.63851 & 10.497 & $0.01^{*}$ \\
\hline $\begin{array}{l}\text { 6. Interpreting } \\
\text { figures of } \\
\text { speech }\end{array}$ & 1.1500 & 3.4000 & 1.14466 & 0.77790 & 10.282 & $0.01^{*}$ \\
\hline $\begin{array}{l}\text { 7. Identifying } \\
\text { basic conflicts }\end{array}$ & 1.5750 & 3.0500 & 0.81296 & 0.59700 & 9.249 & $0.01^{*}$ \\
\hline $\begin{array}{l}\text { 8. Making } \\
\text { predictions }\end{array}$ & 1.7000 & 3.5000 & 0.64847 & 0.64051 & 12.490 & $0.01^{*}$ \\
\hline $\begin{array}{l}\text { 9. Giving } \\
\text { interpretations }\end{array}$ & 1.5250 & 3.0750 & 0.87669 & 0.72986 & 8.594 & $0.01^{*}$ \\
\hline $\begin{array}{l}\text { 10.Identifying the } \\
\text { writer's tone. }\end{array}$ & 1.2000 & 3.3000 & 1.34355 & 0.75786 & 8.610 & $0.01^{*}$ \\
\hline $\begin{array}{l}\text { 11. Forming } \\
\text { Conclusions }\end{array}$ & 1.0250 & 3.4250 & 0.83166 & 0.74722 & 13.576 & $0.01^{*}$ \\
\hline $\begin{array}{l}\text { 12. Evaluating the } \\
\text { quality of the } \\
\text { literary work }\end{array}$ & 1.3500 & 3.5250 & 0.76962 & 0.50574 & 14.937 & $0.01^{*}$ \\
\hline Total & 15.625 & 39.600 & 4.5611 & 3.4626 & 26.478 & $0.01^{*}$ \\
\hline
\end{tabular}

$(*)$ statistically significant difference at 0.01

The above table confirms the $t$ values proved that there is a statistically significant difference at 0.01 between the mean scores of experimental group in the pre-and the posttest in overall literary reading skills and in each sub-skill favoring the post test scores.

The mean scores of the experimental group students in the post administration of the literary reading test (39.600) are higher than their mean scores on the pre-administration (15.625). Thus, the development of the overall literary reading skills of the experimental group students is proved due to the program. Therefore, this provides enough evidence to support hypothesis 1.

A t-test was used to test the second hypothesis of the study which stated that there would be a statistically significant difference between the mean scores of the experimental group in the pre- and the post administrations of the metacognitive reading awareness scale in overall metacognitive reading awareness strategies and each strategy sub-category favoring the post-administration. The results are shown in table (2). 
Reflective Thinking Strategies for Developing EFL Literary Reading Skills and Metacognitive Reading Awareness, Eman Mahmoud Ibrahim Alian

Table (2) t-values of the experimental group in the pre and the post administrations of the metacognitive reading awareness as a whole and in each sub-category of the strategies.

\begin{tabular}{lllllll}
\hline Categories & $\begin{array}{l}\text { Mean } \\
\text { Pre }\end{array}$ & $\begin{array}{l}\text { Mean } \\
\text { post }\end{array}$ & $\begin{array}{l}\text { Pr Std. } \\
\text { Dev }\end{array}$ & $\begin{array}{l}\text { Post Std. } \\
\text { Deviation }\end{array}$ & $\begin{array}{l}\text { t. } \\
\text { Values }\end{array}$ & Sig \\
\hline $\begin{array}{l}\text { Global reading } \\
\text { strategies }\end{array}$ & 19.6250 & 44.6250 & 5.99011 & 4.95977 & 20.331 & $0.01^{*}$ \\
$\begin{array}{l}\text { Problem- } \\
\text { solving } \\
\text { strategies }\end{array}$ & 11.2000 & 26.3000 & 4.34535 & 3.67389 & 16.783 & $0.01^{*}$ \\
$\begin{array}{l}\text { Support } \\
\text { reading }\end{array}$ & 18.8000 & 42.5750 & 5.53868 & 3.84233 & 22.306 & $0.01^{*}$ \\
strategies & 49.6250 & 113.500 & 14.47312 & 10.7273 & 22.424 & $0.01^{*}$ \\
\hline \multicolumn{1}{c}{ Total } & & & & & & \\
\hline
\end{tabular}

The above table confirms the following:

1) The $t$-values revealed that there is a statistically significant difference at 0.01 between the mean scores of the experimental group in the pre- and the past administrations of the metacognitive reading awareness scale in the overall metacognitive reading awareness of strategies and each strategy sub-category favoring the post-administration.

2) The mean scores of the experimental group students in the post administration of the metacognitive reading awareness scale (113.500) are higher than their mean scores in the pre-administration (49.6250). Thus, the development of overall metacognitive reading strategies awareness of experimental group students is proved, due to the program. Therefore, this provides enough evidence to support hypothesis 2 .

These differences could be attributed to:

Practicing reflection through reading enabled readers to clarify the meaning, deepen their understanding, and enrich their minds by analyzing the ideas, points of view, assumptions, and hypotheses presented by the author. Results of this study supported findings from other studies that proved the effectiveness of using reflection for teaching literature such as Brevig (2009) and Spillman, Szecsi, and Montilla (2010). Meanwhile, In practicing reflective thinking strategies, students' awareness became clearer as they recognized when and how to use these strategies while reading literary texts. This finding was also proved by previous studies that utilized reflective thinking for raising metacognition and proved to be effective such as Robson (2010)

Students were motivated to investigate, inquire, and dig beneath the surface to extract the real meanings behind the literary text. Besides, they read, wrote, thought, discussed, analyzed, and criticized what they read. This idea was supported by Douillard (2002: 93) as he stated that reflective activities in the classroom help make thinking more visible, enabling students to learn from one another and to gain greater insights into their thinking and learning processes .

Reflective questions strategy encouraged students not to accept any thought as face value but to try to search for evidence to discover the intended message of the writer. Cranton (2006:138) asserted this point as he mentioned that through thinking about and responding to questions new avenues for understanding and new ways of seeing things are 
opened. In answering questions, learners had an opportunity to search for individually meaningful solutions to problems.

The application of the discussion and retrospective reflection sessions strategies provided students with opportunities to freely express what they were thinking about through reading literary texts. They were also encouraged to discuss, examine, rethink and share these viewpoints with each other. Brevig (2006: 523) supported this point as he indicated that when readers stop to comment on the language of a text or to explore their understanding of it, they are actively engaged in a process to uncover meaning, transacting with both the text and their fellow readers. He added that during retrospective reflection sessions, prior conversations are revisited, offering students the opportunity to observe their evolving perceptions and discuss their ideas with others until they are tangible, explicit, and lucid.

Through writing in journals, students discovered hidden knowledge about the characters, themes, plot, and other different literary elements. They also predicted the coming incidents and made justifications for the characters' behavior. These benefits were confirmed by Holt (2006) as he clarified that the reflective journals help foster and create an environment so students can discover their interpretation, create their meaning, and plan an application.

The use of visualizing strategy also helped students to live the real experience of the literary work. They imagined the appearance, impressions, and facial expressions of the different characters. In illustrating the effective role of using visualization through talking about literature, Short, Kauffman and Kahn (2000: 162) indicated that expressing thoughts through visualizing allows students to express their feelings, try out ideas they have in their minds about the literary work, learn more about it, understand how it felt to live during a specific period and make more connections.

As for the development of students' metacognitive reading awareness, it was also attributed to the use of reflective thinking strategies as students were trained to use these strategies through the different stages of reading. As a result, they became aware of when and how to use a suitable plan for a specific reading situation. Students also utilized reflective thinking strategies for the aim of planning, monitoring, and evaluating their reading, such as activating their background knowledge, anticipating and predicting, writing journals, text look back, and group summarization. In confirming the role of reflective strategies in raising students' awareness, Brevig (2006: 522) stated that looking back at snapshots of reflections students made during the journey of reading offers a new perspective and opportunity for students to gain awareness of their learning process. He added that the exploratory talk and reflection assist students in developing meaning. Through utilizing them, students can self-monitor their learning and develop and nurture evolving ideas.

\section{Conclusion}

It can be found that the reflective thinking strategies encourage students to participate actively through reading literary texts as they are motivated to practice various processes such as thinking deeply about the document, analyzing its essential elements, such as plot, setting, theme, characters, motives, figures of speech, and conflict; making connections between the different characters' lives and their own lives, visualizing the separate incidents of the literary work, predicting what would happen next, and making different inferences. 
Reflective Thinking Strategies for Developing EFL Literary Reading Skills and Metacognitive Reading Awareness, Eman Mahmoud Ibrahim Alian

Through practicing reflective thinking strategies, students also manage to create their meanings of the literary text, reexamining and refining them through questioning the validity of the document, searching for supporting evidence, sharing, and discussing their viewpoints. At the same time, they are encouraged to freely express their ideas, listen to different opposing points of view, and respect them. This is achieved through the instructor's encouragement and the unthreatening environment provided by reflective thinking, which in turn offers a medium for a productive discussion.

Besides, through utilizing reflective thinking strategies, students can practice higherorder thinking skills such as analyzing, evaluating, and criticizing what they read. They manage to do so through asking thoughtful questions, engaging in a literary conversation about the characters' behaviors, attitudes, and motivations, analyzing their responses, and criticizing them for gaining insights into the human nature behavior and for deriving moral lessons which are the ultimate goals of reading literature.

In addition to the previous benefits of reflective thinking strategies, it could be stated that through practicing these strategies, students gained awareness in their learning. They managed to know when, why, and how to use such an approach through reading literary texts. At the same time, they could plan their learning, monitored their understanding, and evaluated the use of strategies to enhance their knowledge. Therefore, students' metacognitive awareness was improved and expanded.

\section{References}

Al-Hazmi, S. (2006). Writing and Reflection: perceptions of Arab EFL Learners. Asian Language Review, xvi (2).

Andrusyszyn, M. (1996). Facilitating Reflection in Computer Mediated Environment (Published Ph.D. Thesis). Graduate Department of Education, University of Toronto.

Auerbach, E., \& Paxton, D. (1997). "It's not the English thing": Bringing reading research into the ESL classroom. TESOL Quarterly, 31, 237-261.

Blank, L. (2000). A metacognitive learning cycle: A better warranty for student understanding. Science Education, 84(4), 486-506.

Brevig, I. (2009). The Fishbowl and the Flies: A Classroom Study of the Relationships between Book Clubs, Talk, Reflection and Community (published Ph.D. Thesis). Hofstra University.

Chi, F. (1997). Reflexivity as a learning strategy in EFL. A paper presented at the First panAsian Conference and the Annual international meeting of the Thai Teachers of English to Speakers of Other Language.

Costa, A. \&Kallick, B. (2000). Getting into the habit of reflection, Educational leadership, 57(7), 60-63.

Cranton, P. (2006). Understanding and promoting transformative learning: A guide for educators of adults (2nd ed.). San Francisco, CA: Jossey-Bass.

Davenport, M. (1993). Reflecting through talk on content area reading. In K. Pierce \& C. Gilles (Eds.), Cycles of meaning (179-196). Portsmouth, NH: Heinemann.

Douillard, K. (2002). Going past done: Creating time for reflection in the classroom. Language Arts, 80, 92-99.

El-Henawy, W. (2007). Using a Visualization-Based Approach for Developing the Skills of Reading a Literary Text among English Department Students in Faculties of Education (Unpublished M.A. Thesis). Faculty of Education, Mansoura University. 
Flavell, J. (1979). Metacognition and cognitive monitoring: A new area of cognitivedevelopmental inquiry. American Psychologist, 34, 906-911.

Geertsen, H. (2003). Rethinking Thinking about Higher-Level Thinking. Teaching Sociology, 31(1), 1-19.

Harvey, S. \&Goudvis, A. (2000). Strategies that work. York, ME: Stenhouse.

Hennings, D. (1992). Beyond the read aloud: To read through listening to and reflecting on literature. Eric Research Report [ED 357318].

Holt, K. (2006). Looking Backward, Living Forward: a Case Study of critical Reflection in Journals in a University Literature Classroom. (Published Doctoral Dissertation), University of Idaho, Brigham.

Hudson, T. (2007). Teaching second language reading. Oxford, England: Oxford University Press.

Josten, I. (2011). Reflective Thinking: A Tool for Professional Development in Educational Practice (published Ph.D. Thesis). Walden University.

Kuhn, (1999). Writing toward thoughtfulness through logs. In L. Reid and J.Gloub. Reflective activities: Helping students connect with texts. Classroom practices in teaching English series (74-86). National Council of Teachers of English, Urbana, IL.

Lai, E. (2011). Critical thinking: A literature review. Pearson's Research Reports, 6.

Lazer, G. (2005). Literature and Language Teaching: a guide for Teachers and trainers (2nd Ed.). Cambridge: Cambridge University Press.

Mezirow, J. (1991). Transformative dimensions of adult education. San Francisco: Jossy Bass.

Mokhtari, K., Sheorey, R. (2002). Measuring ESL students' awareness of reading strategies. Journal of Developmental Education 25, 2-9.

Nottingham, J.A. (1998). Using Self Reflection for Personal and Professional Development in Student Affairs. New Directions for Student Services, 84, 71-81.

Reid, L. \& Golub, J. (1999). Reflective activities: Helping students connect with texts. Classroom practices in teaching English series, 30, National Council of Teachers of English, Urbana, IL.

Richardson, J., Morgan, R., and Fleener, C. (2009). Reading to Learn in the Content Areas $\left(7^{\text {th }}\right.$ Ed.). Belmont, CA: Thomas Higher Education.

Sawira, Suhadi, J. and Manugeren (2017). Heroism in Lin Carter's Novel the Quest of Kadgi. Language Literacy: Journal of linguistic, literature, and Language Teaching, 1 (1), 119140.

Scanlan, J., Care, W. \& Udod, S. (2002). Unraveling the Unknowns of reflection in classroom teaching. Journal of Advanced Nursing, 38 (2), 136-143.

Schraw, G., \& Dennison, R. (1994). Assessing metacognitive awareness. Contemporary Educational Psychology, 19, 460-475.

Shang, H. (2006). Content-based Instruction in the EFL Literature Curriculum. The Internet TESL Journal, XII (11).

Sheorey, R., \& Mokhtari, K. (2001). Differences in the metacognitive awareness of reading strategies among native and nonnative readers. System, 29(4), 431-449.

Shermis, S. (1999). Reflective Thought, Critical Thinking. ERIC Clearinghouse on Reading English and Communication, Bloomington Indiana, [ED436007]. Retrieved from: http://www.ericfacility.net/databases/ERIC_Digests/ed436007.html

Short, K. G., Kauffman, G., \& Kahn, L. (2000). I just need to draw: Responding to literature across multiple sign systems. The Reading Teacher, 54(2):160-171. 
Reflective Thinking Strategies for Developing EFL Literary Reading Skills and Metacognitive Reading Awareness, Eman Mahmoud Ibrahim Alian

Spillman, C., Szecsi, T., Montilla, E. (2010). Transforming Teacher Cultural Landscapes by Reflecting on Multicultural Literature. Multicultural Education, 17 (4), 44-48.

Ur, P. (1996). A Course in Language Teaching. Cambridge: Cambridge University Press.

Van, T. (2009). The relevance of literary analysis to teaching literature in the EFL classroom. English Teaching Forum, (3), 2-9.

Zayed, J. (2009). The effectiveness of Reflection in Developing Students' Oracy in English at the Faculties of Tourism and Hospitality (unpublished M.A. Thesis). Faculty of Education, Mansoura University. 